
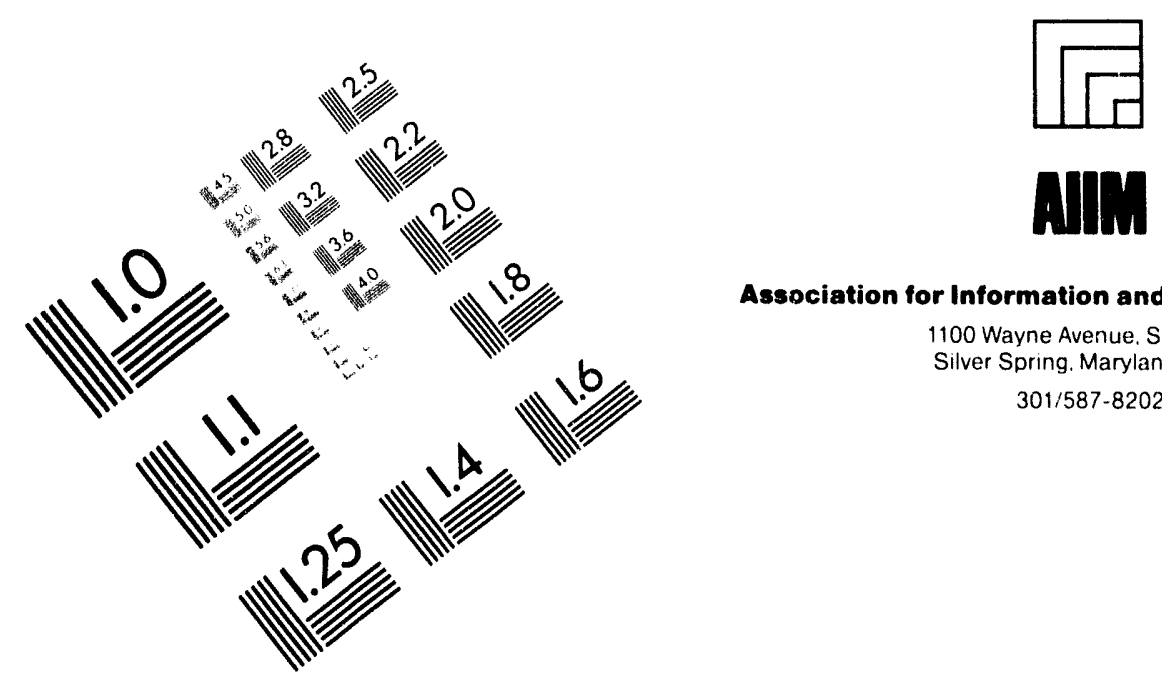

Association for Information and Image Management

1100 Wayne Avenue. Suite 1100

Silver Spring. Maryland 20910

$301 / 587-8202$

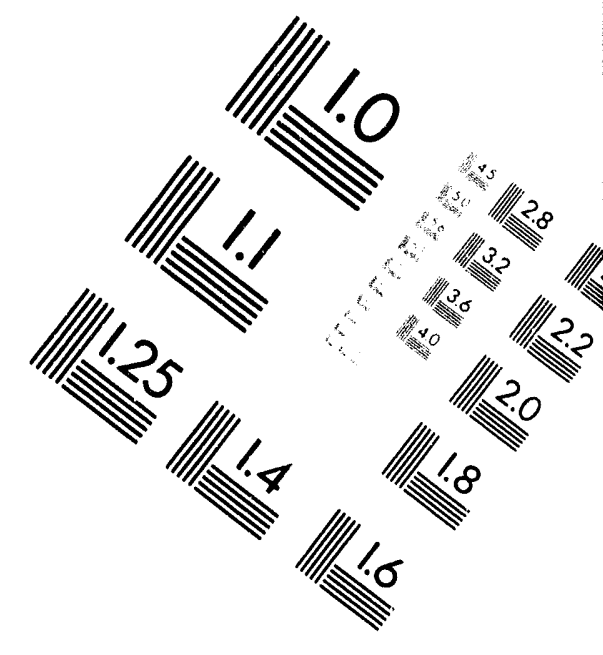

Centimeter

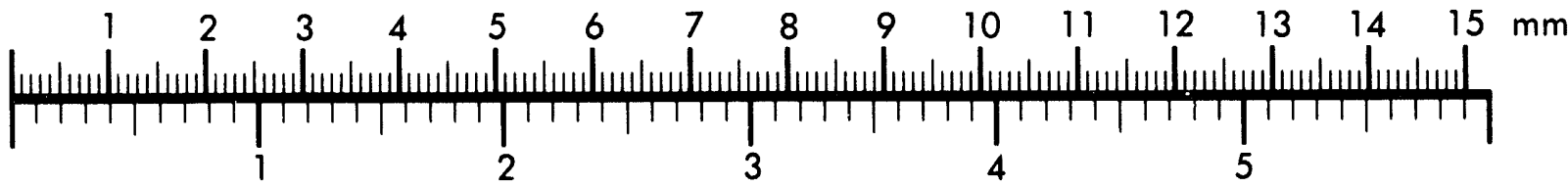
Inches
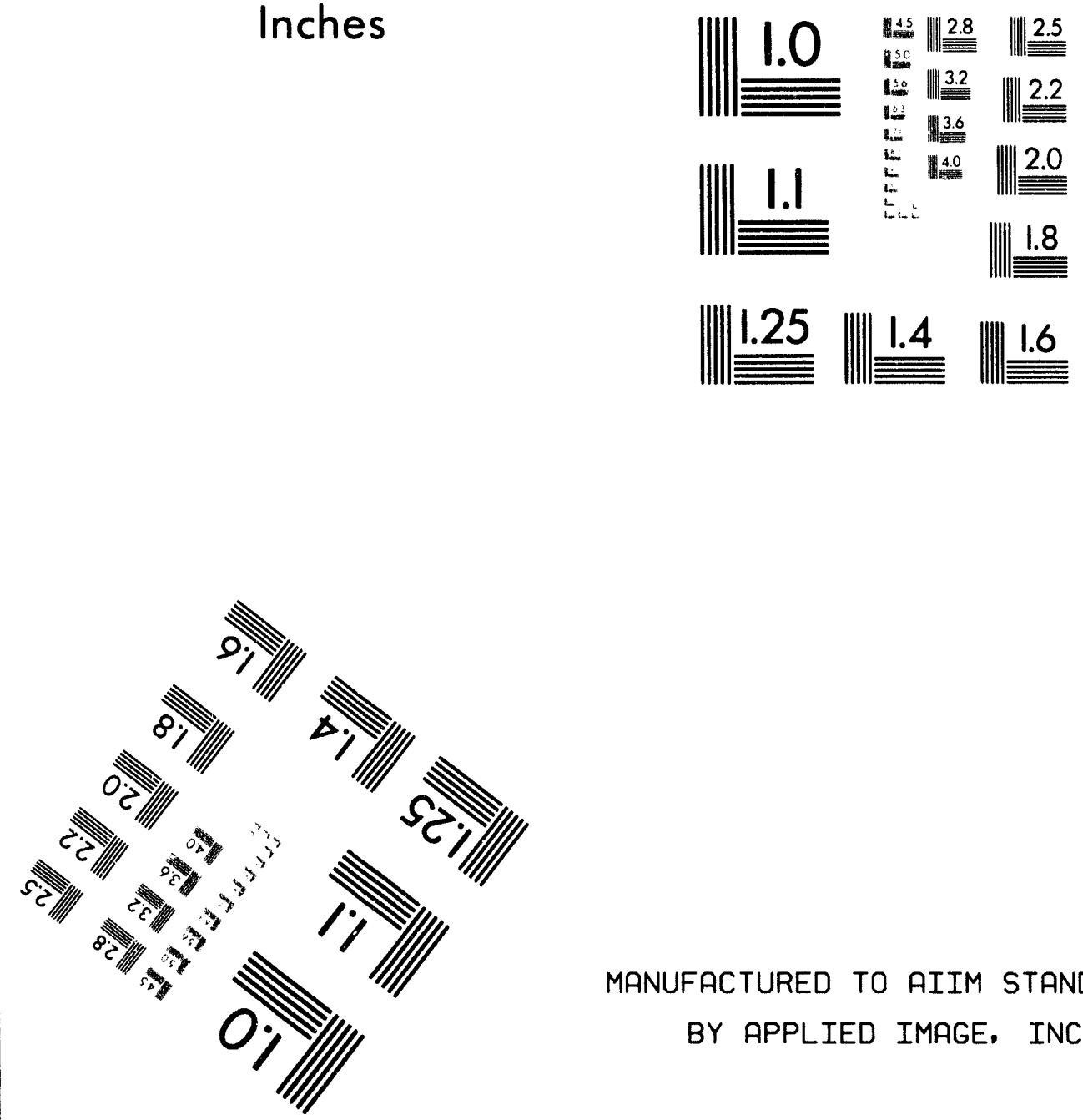

MANUFACTURED TO AIIM STANDARDS BY APPLIED IMAGE, INC.

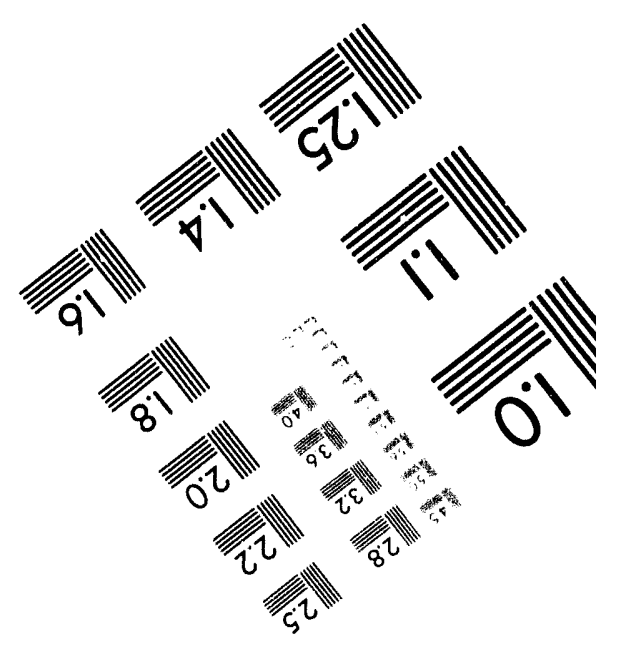


.
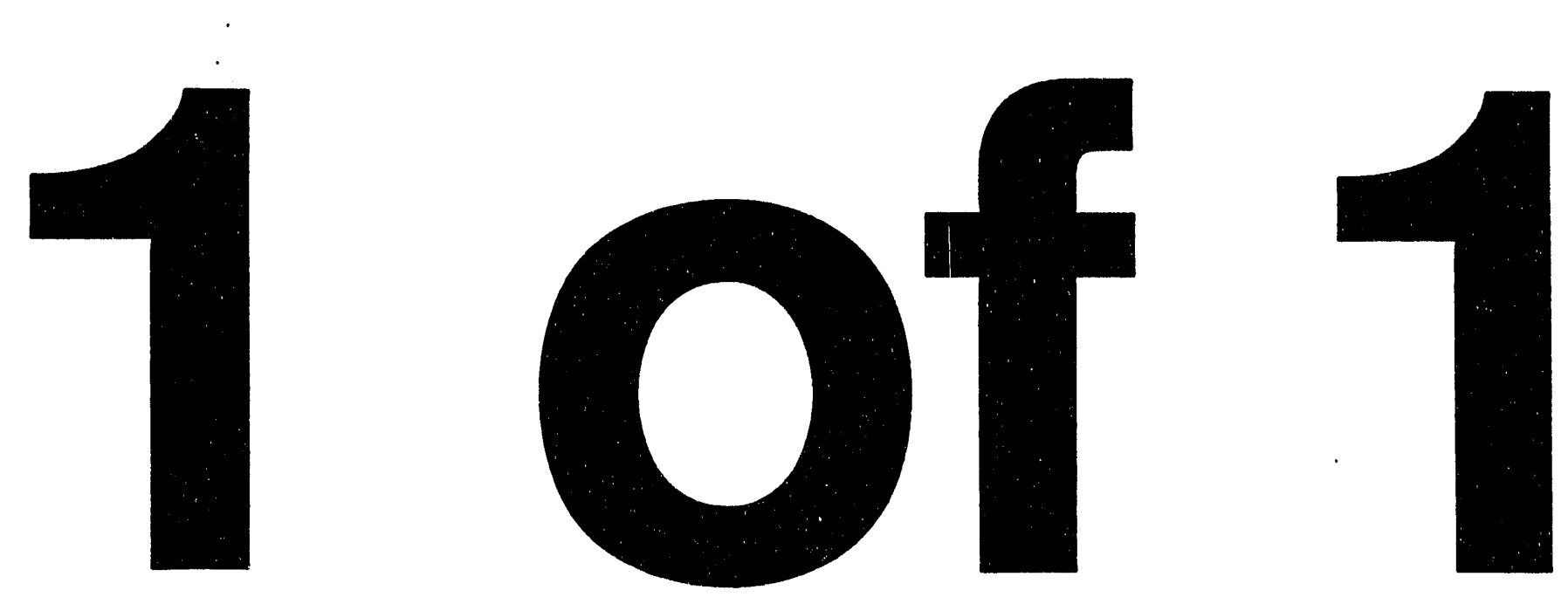
DOE/SR/18049-5

\title{
PHYSIOLOGICAL ECOLOGY OF SRS CAROLINA BAY PHYTOPLANKTON COMMUNITIES: EFFECTS OF NUTRIENT CHANGES AND $\mathrm{CO}_{2}$ SOURCES \\ Renewal Year Two Report
}

John B. Williams

\author{
Department of Natural Sciences \\ South Carolina State University \\ Orangeburg, S.C. 29117
}

\begin{abstract}
"This report was prepared as an account of work sponsored by an agency of the United States Government. Neither the United States Government noir any agency thereof, nor any of their employees, makes any warranty, express or implied, or assumes any legal liability or responsibility for the accuracy, compicteness, or usefulness of any information, apparatus, product, or process disclosed, or represents that its use would not infringe privately owned rights. Reference herein to any specific commercial product, process, or service by trade name, trademark, manufacturer, or otherwise, does not necessarily constitute or imply its endorsement, recommendation, or favoring by the United States Government or any agency thereof: The views and opinions of authors expressed herein do not necessarily state or reflect those of the United States Government or any agency thereof."
\end{abstract}

Date Published - December 1993

PREPARED FOR THE

U.S. DEPARTMENT OF ENERGY

UNDER CONTRACT DE-FG09-88SR18049

MASTER

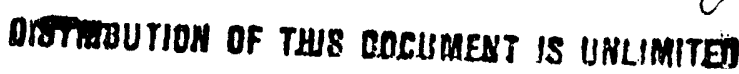




\section{GENERAL PROJECT BACKGROUND:}

Impacts of land-use activities on wetland ecosystems, their resiliency, restoration, and related topics continue to be front-page issues for environmental planners, conservation groups, and government agencies. Among the abundant wetland systems within the United States Department of Energy (DOE) Savannah River Site (SRS) are unique aquatic environments known as Carolina bays. Carolina bays represent especially critical habitat areas because they are the only naturally occurring aquatic systems above the floodplain in otherwise dry upland areas. Previous DOEfunded wetlands research at SCSU has produced results concerning important relationships between phytoplankton (part of the food-web base), water chemistry, and higher food chain levels in Carolina bay wetlands at SRS. Carolina bays within South Carolina have been described as "relatively endangered systems" with only 4,000 bays existing in the State (Bennett and Nelson, 1991). With greater than 150 larger Carolina bays within SRS borders (Shields, et al., 1982), these research and management efforts take on added significance.

Developing a clear understanding of the functional roles of phytoplankton and their responses to water chemistry is essential if natural ecosystem integrity is to be maintained through Carolina bay conservation and restoration efforts. The main objective of this second renewal year project effort was to determine the primary sources of $\mathrm{CO}_{2}$ for algal photosynthesis and the $\mathrm{CO}_{2}$ exchange flows between bottom sediments, water column, and the atmosphere. This objective was designed to quantify a portion of the role that these wetlands play in $\mathrm{CO}_{2}$ cycling through the actions of decomposition, atmospheric diffusion, and algal photosynthesis. An additional objective was to continue to measure the patterns of phytoplankton community dynamics and changes in water chemistry in Flamingo Bay and Lost Lake for comparison with previous years. The continued population sampling and chemical analyses were designed to evaluate effects of potential nutrient increases resulting from fertilizing in Lost Lake restoration efforts.

\section{SUMMARY STATUS OF RENEWAL YEAR TWO OBJECTIVES:}

Progress on Renewal Year Two objectives has included the completion of all objectives except a few statistical analyses and final report production and recommendations. All stable carbon isotope sampling and carbon dioxide flux experiments have been completed. Water chemistry, phytoplankton, and zooplankton samples have all been analyzed and computerized. Extensive recounts were made to verify initial phytoplankton and zooplankton counts for several sample stations and dates to evaluate statistical precision and assure quality control. The final report will contain detailed methodologies, results, and conclusions of the project tasks summarized below as 
well as recommendations relevant to DOE wetlands restoration efforts and aquatic environmental impacts.

\section{PROGRESS ON SPECIFIC OBJECTIVES:}

\section{Objective: Determine the relative use by phytoplankton in Carolina bays of atmospheric $\mathrm{CO}_{2}$ versus $\mathrm{CO}_{2}$ derived from in-situ decomposition .}

Research on this objective focused on: 1) determining the main source of $\mathrm{CO}_{2}$ for algal photosynthesis using stable carbon isotope analysis and 2) quantifying the $\mathrm{CO}_{2}$ exchange processes to determine this wetland's role in $\mathrm{CO}_{2}$ cycling. As restored wetlands reestablish phytopiankton communities, the relative availability of $\mathrm{CO}_{2}$ throughout the water column may play a selective role in the composition and rate of algal community development.

The stable carbon isotope ratios in phytoplankton should directly reflect relative algal use of a particular $\mathrm{CO}_{2}$ source. (As demonstrated by laboratory experimental $\mathrm{CO}_{2}$ treatments in previous years' research under this SCSU grant.) $\mathrm{CO}_{2}$ diffusing into the water column primarily from pore waters and decomposition of aquatic plant matter by bacteria in the sediments will exhibit a $\partial^{13} \mathrm{C}$ that is less negative than the $\partial^{13}$ of $\mathrm{CO}_{2}$ diffusing from the atmosphere. (As described in Rau and Anderson (1981), the ${ }^{13} \mathrm{C} /{ }^{12} \mathrm{C}$ of a sample is represented as $\partial^{13} \mathrm{C}$ where:

$\left.\partial^{13} \mathrm{C}=\left\{\left[{ }^{13} \mathrm{C} /{ }^{12} \mathrm{Csample}\right) /\left({ }^{13} \mathrm{C} /{ }^{12} \mathrm{C} \mathrm{PDB}\right)\right]-1\right\} \times 10^{3}$ per mil. $\partial^{13} \mathrm{C}$ of a sample is the relative ppt difference between the ${ }^{13} \mathrm{C} /{ }^{12} \mathrm{C}$ of the sample and the ${ }^{13} \mathrm{C} /{ }^{12} \mathrm{C}$ of the PeeDee belemnite standard. Interpreting these $\partial^{13} \mathrm{C}$ results is complicated because water column mixing can present a combination of the two $\mathrm{CO}_{2}$ sources to algae ard because some algal species have self motility. The most abundant species in the unimpacted SRS Carolina bays are flagellated chlorophytes with swimming abilities capable of moving between bottom and surface layers. Wind-driven vertical mixing in some Carolina bays (e.g. Flamingo Bay) is greatly restricted by the sheltering effect of adjacent forests and by the dampening effect of aquatic vegetation (e.g. Panicum sp. and Brasenia schreberi) on wave generation. Seasonally distinct thermoclines and sharply stratified dissolved oxygen were also observed in the unimpacted bays, further indicating low seasonal mixing. For these reasons vertical migrations by flagellated chlorophytes would be the main factor complicating interpretations of $\mathrm{CO}_{2}$ uptake. Unlike the older, heavily vegetated bays, Lost Lake would be more thoroughly mixed due to its larger open water surface area.

Samples for $\partial^{13} \mathrm{C}$ analysis in Flamingo bay algae and water were collected on two dates during spring 1993. The same methods were used on both March 30, 1993 and May 18, 1993 for collecting and processing water and algal tissue samples for GC mass spectrometry analysis. Water for ${ }^{13} \mathrm{C}$ samples was pumped from the upper $10 \mathrm{~cm}$ of the water column for surface samples and 
from the lower $10 \mathrm{~cm}$ of the water column for bottom samples. Incoming water was prefiltered through $63 \mu$ mesh nylon netting (nitex) to remove zooplankton and any large detritus (from bottom waters). For $\partial^{13} \mathrm{C}$ water samples, $500 \mathrm{ml}$ of water were pumped into high density polyethylene bottles and stored on ice before being frozen at the laboratory. A total of 6 surface water samples and 3 bottom water samples were collected on each date.

Phytoplankton tissue was concentrated from surface waters and bottom waters by filtration and centrifugation. Sufficient volumes of water were collected in the field by pumping bay water (prefiltered through $63 \mu$ mesh) into 25 liter nalgene carboys for each sample. Three samples were collected from the surface waters and 3 samples from bottom waters. At the laboratory each sample was refiltered through a $63 \mu$ mesh sieve and the filtrate collected in a 25 liter carboy and saved for further separation of phytoplankton. Zooplankton and detrital particles were found to be almost. entirely retained on the $63 \mu$ mesh sieve. For this reason the suspended particles in the filtrate were assumed to be nearly all phytopiankton. (This assumption was validated by microscopic examination of phytoplankton samples, however a low percentage of very small detrital particles were also present in the filtrate.)

Each phytoplankton tissue sample was removed from suspension by pumping the ca 25 liters of original filtrate through a $2.0 \mu$ mesh tangential flow filter (acroflux capsule) using a centrifugal pump with a maximum pressure head of $15 \mathrm{psi}$ (Micropump). The filter retentate was next centrifuged (Retentate not immediately centrifuged was stored at $5^{\circ} \mathrm{C}$.) to concentrate the algae and oven-dried in scintillation vials at $75^{\circ} \mathrm{C}$ for $2-3$ days in preparation for $\mathrm{GC}$ mass spectrometry analysis. These phytoplankton samples represented the combined tissues of several algal species, however the species percent composition was enumerated by microscopic counts. Dried samples were stored in a desiccator prior to shipment to Coastal Sciences Laboratories, Inc. for GC mass spectrometry analysis.

In order to provide additional stable carbon isotope samples to further analyze trophic relationships between phytoplankton and zooplankton, zooplankton samples were collected from surface and bottom water in the field. After being filtered out by pumping bay water through a $63 \mu$ mesh nylon (nitex) sieve, zooplankton samples were frozen until time for further analysis. The mixture of zooplankton and detritus from the $63 \mu$ sieve was later subdivided and separated microscopically and zooplankton were divided into taxonomic groups and dried at $75^{\circ} \mathrm{C}$ for $2-3$ days for later GC mass spectrometry analysis.

Final statistical analyses are being completed, however the $\partial 13$ of phytoplankton is closer to the $\partial^{13}$ of surface water $\mathrm{CO}_{2}$ than to the $\partial^{13}$ of $\mathrm{CO}_{2}$ present in bottom water (Table 1.). The source of higher $\partial^{13} \mathrm{CO}_{2}$ in these hypolimnion waters is likely a by-product of methanogenesis in the bottom sediments as described by (Herczog, 1987). 
Table 1: Mean phytoplankton and water $\partial^{13}$ for samples collected at Flamingo Bay on March 30 and May 18, 1994.

\author{
Surface water $\partial^{13}$ Bottom water $\partial^{13}$ Phytoplankton $\partial^{13}$
}

$-15.2$

$-10.2$

$-26.6$

In order to measure $\mathrm{CO}_{2}$ exchange rates between the water column, sediments, and atmosphere, different experimental diffusion chambers were used. The shallow depth $(<1.0 \mathrm{~m})$ of most Flamingo Bay submerged areas made it possible to insert PVC pipes (4 in. diameter) into the sediments and have them extend above the water surface. Our basic methodology involved: removing the ambient bay water from the columns; replacing this water with water of known $\mathrm{CO}_{2}$ concentrations and $\partial^{13} \mathrm{C}$; and then sampling $\mathrm{CO}_{2}$ changes over time and depth. Additional samples were collected from adjacent open water areas to serve as controls.

Similar laboratory preparation steps were followed for all field $\mathrm{CO}_{2}$ flux experiments. Large volumes ( 100 to $150 \mathrm{l}$ ) of water collected from Flamingo Bay prior to the experiment were filtered through $63 \mu$ mesh nylon (nitex) netting to remove zooplankton and detritus. For treatments requiring $\mathrm{CO}_{2}$-free water, nitrogen gas was bubbled vigorously throughout the 251 nalgene carboys of water to drive off other dissolved gases. $\mathrm{CO}_{2}$ concentrations were determined through standard $\mathrm{NaOH}$ titration methods (APHA, 1985) to verify the completeness of $\mathrm{N}_{2}$ degasing. For water treatments involving known levels of $\mathrm{CO}_{2}$, the $\mathrm{CO}_{2}$ treatment concentrations were produced by bubbling compressed commercial $\mathrm{CO}_{2}$ gas into the water.

The first $\mathrm{CO}_{2}$ exchange experiment was begun on July 22, 1993. Two different treatments were randomly assigned to five stations each. Initial preparation steps were the same for each PVC pipe ( 4 in. dia. $x 30$ in.). After the pipe was driven into the sediment to a depth of $\mathrm{ca} \geq 10 \mathrm{~cm}$, the water inside was removed using a nalgene $1000 \mathrm{ml}$ bottle converted into a bailer by installing a oneway flap valve in its bottom. After the bottom sediments were exposed, any residual water and near surface pore water were removed by pressing a sponge against the sediments. (This also served to liberate any $\mathrm{CO}_{2}$ bubbles which may have accumulated beneath surface sediments or detritus.)

Following these initial preparation steps, the different water treatments were poured slowly into the PVC pipes with a temporary plastic sheet covering the bottom to avoid mixing the sediments by the inflowing water turbulence. The first treatment (OD) consisted of degased water in a pipe open at both ends; allowing gas exchange at both the sediment-water and water-air interfaces. The second treatment (TD) also had degased water, but exchange was only permitted at the sediment-water interface. Exchange at the water-air surface in TD was blocked by a sheet of heavy guage polyethylene held tightly in place by a PVC collar. 
After each OD or TD rreatment unit was established, an initial $250 \mathrm{ml}$ water sample was collected for $\mathrm{CO}_{2}$ concentration analysis and a $500 \mathrm{ml}$ sample was collected for $\partial^{13} \mathrm{C}$ analysis. Water samples were stored on ice for transportation to the laboratory where $\mathrm{CO}_{2}$ concentration samples were immediately titrated and GC mass spectrometry samples were frozen for later analysis. Treatments OD and TD pipes were sampled at the top $5 \mathrm{~cm}$ and bottom $5 \mathrm{~cm}$ of the water column for $\mathrm{CO}_{2}$ concentration on July 22, 23, and 261994 (days 1, 2, and 5 of the experiment). On the final sampling day (day 5) $500 \mathrm{ml}$ water samples for $\partial^{13} \mathrm{C}$ analysis were collected from both the top $5 \mathrm{~cm}$ and bottom $5 \mathrm{~cm}$ of the water column in each pipe. All water samples were stored on ice for transportation and the samples for $\mathrm{CO}_{2}$ concentration were titrated immediately upon return to the laboratory. Samples for $2^{13} \mathrm{C}$ analysis were frozen until GC mass spectrometry analysis. The purpose of this experiment was to determine the rate of $\mathrm{CO}_{2}$ diffusion through the water column and the relative contribution of atmospheric $\mathrm{CO}_{2}$ versus decomposition $\mathrm{CO}_{2}$ to the water column.

A second replication of the $\mathrm{CO}_{2}$ exchange experiment was begun on August 17, 1994. The experimental design was similar to the first replication, however two additional new treatments were added. The two new treatments differed from OD and TD in that the bottom of both pipes was sealed by heavy guage polyethylene secured by a PVC collar to prevent diffusion of $\mathrm{CO}_{2}$ into the pipe from sediment pore waters. All pipes were filled with their respective treatment waters until pipe water level equaled the surrounding bay water outside. One pipe (BC) was filled with water enriched with compressed gas $\mathrm{CO}_{2}$ ( $\mathrm{ca} 20 \mathrm{ppm}$ ). The other pipe (BN) was filled with degased water with $0 \mathrm{ppm} \mathrm{CO}_{2}$. Each pipe was sampled on August 17, 19, 24, and 31 (days 1, 3, 8, and 15 of the experiment).

After each treatment unit was established, an initial $250 \mathrm{ml}$ water sample was collected for $\mathrm{CO}_{2}$ concentration analysis and a $500 \mathrm{ml}$ sample was collected for $\partial^{13} \mathrm{C}$ analysis. Water samples were stored on ice for transportation to the laboratory where $\mathrm{CO}_{2}$ concentration samples were immediately titrated and GC mass spectrometry samples were frozen for later analysis. Treatments $\mathrm{OD}, \mathrm{TD}, \mathrm{BC}$, and $\mathrm{BN}$ pipes were all sampled at the top $5 \mathrm{~cm}$ and bottom $5 \mathrm{~cm}$ of the water column for $\mathrm{CO}_{2}$ concentration on days $1,3,8$, and 15 of the experiment. On the final sampling day (day 15) $500 \mathrm{ml}$ water samples for $\partial^{13} \mathrm{C}$ analysis were collected from both the top $5 \mathrm{~cm}$ and bottom $5 \mathrm{~cm}$ of the water column in each pipe. All water samples were stored on ice for transportation and the concentration samples were titrated immediately upon return to the laboratory. Samples for $\partial^{13} \mathrm{C}$ analysis were frozen until GC mass spectrometry analysis. As with the first replication, this experiment was designed to determine the rate of $\mathrm{CO}_{2}$ diffusion through the water column and the relative contribution of atmospheric $\mathrm{CO}_{2}$ versus decomposition $\mathrm{CO}_{2}$ to the water column.

An additional $\mathrm{CO}_{2}$ diffusion experiment was conducted between August 24 and September 10, 1993. $\mathrm{CO}_{2}$ diffusion samples were constructed by filling a $500 \mathrm{ml}$ clear glass bottle with degased water (by $\mathrm{N}_{2}$ bubbling); covering its opening with dialysis membrane and sealing the 
degased water (by $\mathrm{N}_{2}$ bubbling); covering its opening with dialysis membrane; and sealing the membrane tightly with rubber bands. (Pre-testing of this method showed no leakage occurred.) Treatments consisted of bottles being placed: 1) just beneath the bay surface (S); at middepth (M); and at the bottom surface (B). Pairs of bottles for each treatment were attached to upright PVC support poles ( 2 in dia. $\times 5$ feet high) at each sampling depth. Each pipe was driven into the bottom and placed as a series of 10 samples along a transect in the middle of Flamingo Bay. One member of each pair was a sample for $\mathrm{CO}_{2}$ concentration, while the other was a sample for ${ }^{13} \mathrm{C}$ analysis for a particular depth. All bottles were filled from the same water source and so initial $\mathrm{CO}_{2}$ concentrations and $\partial^{13} \mathrm{C}$ were determined from this common water source. Samples for $\partial^{13} \mathrm{C}$ analysis were frozen until GC mass spectrometry analysis. Five control samples of ambient bay water were collected at all three depths along the transect for comparison with the treatment bottles. Final samples were collected after 17 days and stored on ice for transportation. The $\mathrm{CO}_{2}$ concentration samples were titrated immediately upon return to the laboratory while samples for $\partial^{13} \mathrm{C}$ analysis were frozen until GC mass spectrometry analysis.

The purpose of this experiment was to characterize the longer term diffusion transfer of $\mathrm{CO}_{2}$ from different water depths. $\mathrm{CO}_{2}$ diffusion into the jars would continue until an equilibrium was reached with natural water $\mathrm{CO}_{2}$. The $\partial^{13} \mathrm{C}$ in each jar should then represent a cumulative sampling of the natural water $\mathrm{CO}_{2}$ available for diffusion and therefore serve to determine the relative contribution of the atmosphere or decomposition to $\mathrm{CO}_{2}$ at different depths. Unlike the first experiment in which potential vertical mixing was prevented by the pipe surrounding the water column sample, the bottle samplers in this experiment would take up whatever $\mathrm{CO}_{2}$ was presented to them during the 17 day sampling interval. Results of this experiment will help to better interpret the pipe-enclosed water column experimental results and to determine the occurrence of vertical mixing and movement of $\mathrm{CO}_{2}$ through the water column. Results of these $\mathrm{CO}_{2}$ exchange experiments are being analyzed statistically for final manuscript preparation.

Phytoplankton and water chemistry samples were collected periodically during winter, spring, summer, and fall 1993 for comparison with previous cycles of phytoplankton and zooplankton abundance. Sampling and analytical methods were identical to previous years and statistical analyses of computerized files are presently being completed.

\section{REFERENCES:}

APHA. 1985. Standard methods for the examination of water and wastewater. 16 th Ed. APHA. Washington. $1268 \mathrm{p}$.

Rau, G.H. and N.H. Anderson. 1981. Use of $13 \mathrm{C} / 12 \mathrm{C}$ to trace dissolved and particulate organic matter utilization by populations of an aquatic invertebrate. Oecologia (Berl) 48: 19-21.

Herczeg, A.L. 1987. A stable carbon isotope study of dissolved inorganic carbon cycling in a softwater lake. Biogeochemistry 4: 231-263. 

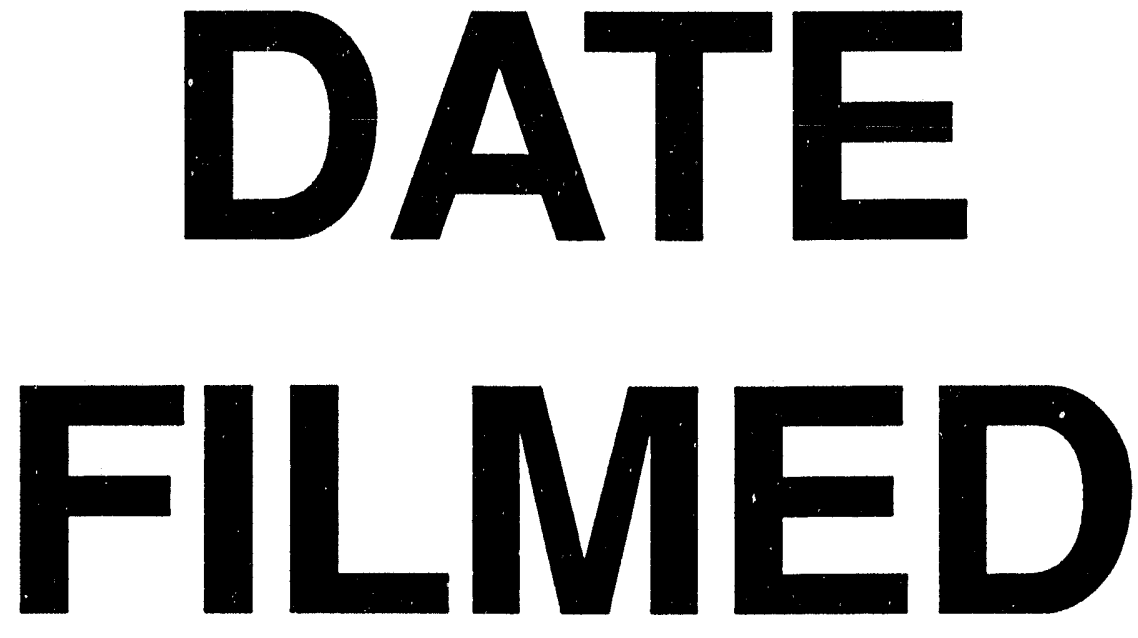

$6 / / 6 / 94$
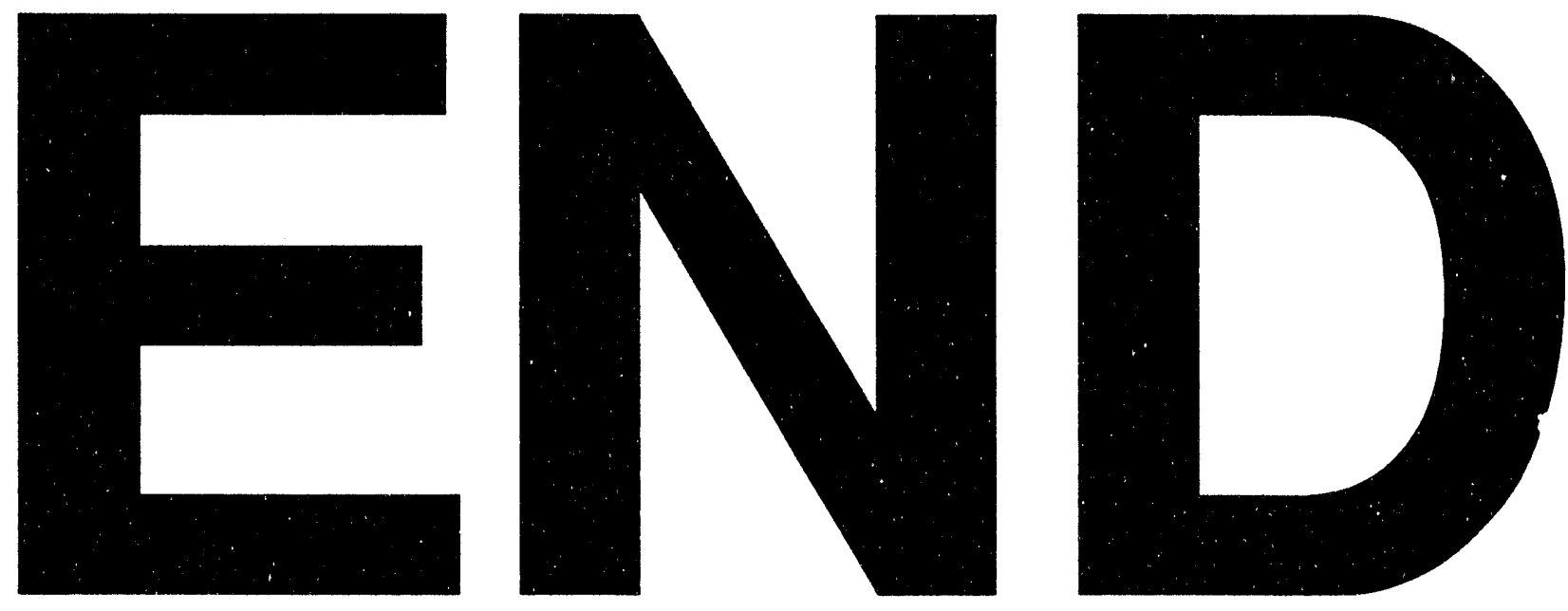
